\title{
An Investigation Into The Livelihoods Strategies Of Informal Women Traders In Zimbabwe
}

Stella Takaza ( $\sim$ stellatakaza@gmail.com )

University of Zimbabwe

Chipo Chitereka

University of Zimbabwe

Research

Keywords: Flea Markets, Micro Credit Schemes, Poverty, Informal Women Traders

Posted Date: April 20th, 2020

DOI: https://doi.org/10.21203/rs.3.rs-22701/v1

License: (9) (1) This work is licensed under a Creative Commons Attribution 4.0 International License.

Read Full License 


\section{Abstract}

This article investigated the livelihoods strategies of informal women traders doing business at flea markets in Zimbabwe. The study was conducted in Harare Province at a flea market near the Harare Central Business District. The study was informed by the Sustainable Livelihood Approach proffered by the Swedish International Development Cooperation Agency Division (SIDA, 2001) for Policy and SocioEconomic Analysis. A qualitative design was utilised and data was gathered through interviews, focus group discussions and observations during transect walks. The specific objectives of the study included the following; to discover micro credit schemes used by the informal women traders doing business at this particular flea market, to explore the impact of microcredit schemes as pathways towards poverty eradication amongst informal women traders; to examine the survival and coping challenges experienced by women doing business under socio-economic environment hardships and finally, to determine possible interventions and sustainable strategies that could be used to out-scale and throw a lifeline to the informal women traders. The study revealed that while women informal traders engaged in diverse activities for their sustainable livelihoods strategies that eradicate poverty, vast majority of informal women traders encountered numerous challenges, resulting in them employing unpleasant survival and tough coping techniques. The study concluded that if financing institutions and Non Governmental Organizations could give them small funds for capacity building for local empowerment; this would help them to gain access and control of their sustainable livelihoods resources in a meaningful way. The study is therefore proposing sound policy interventions and sustainable strategies that could be used to empower informal women traders doing business at flea markets for them to gain access and full control over livelihoods resources in Zimbabwe.

\section{Introduction}

Internationally, particularly in developing countries including Zimbabwe, the informal sector plays fundamental roles to eradicate poverty. Mupambireyi (2014) reveal that, be it in developed or developing countries, economic activities can be broadly categorized into two; formal and informal sector the world over. Whereas salaried workers in the formal sector denote workers in registered enterprise, unsalaried workers in the informal sector represent workers in the unregistered businesses or activities for poverty eradication. Poverty as defined by the Zimbabwe Poverty Report (ZPR) (2017) refers to; "the inability to attain a level of well-being constituting a realistic minimum as defined by society".

This study investigated the livelihoods strategies of women in the informal sector engaged in Micro Credit Schemes, (MCSs) at a flea market for poverty eradication in Zimbabwe. Mugabi (2010) describes MCSs as the easily repayable small loans that low income earners get informally from people in the same network, and from formal credit lending institutions like banks and microfinance institutions. The prime objectives included; to discover micro credit schemes used by informal women traders doing business at flea markets; to examine the survival and coping challenges experienced by informal women traders doing business at flea markets under socio-economic environmental hardships and ultimately, to determine interventions and sustainable strategies that could be used to out-scale and throw a lifeline to 
the informal women traders. The study was informed by the Sustainable Livelihoods Framework proffered by Swedish International Development Cooperation Agency (SIDA, 2001); a Division for Policy and Socio-Economic Analysis; specifically an action programme to promote sustainable livelihoods for the poor.

\section{Background To The Study}

The United Nations Systems; regional commissions, international, regional financial institutions and other donor agencies are concerned with endless efforts to eradicate poverty amongst the most vulnerable groups. The United Nations Decade for the Eradication of Poverty (1997-2006); the United Nations Millennium Development Goals (UNMDG, 2015) and the Sustainable Development Goals, (2015) initiatives for example highlight the need to eradicate poverty. All the stakeholders explored together in coming up with the 2030 Sustainable Development Goals (SDGs); especially Goal No 1 with a thrust to end extreme poverty in all its forms everywhere. The stakeholders agreed at the global level on the Sustainable Development Goals (SDGs, 2015) as an important framework for poverty reduction the world over. As indicated earlier, many countries have adopted the various poverty devices for poverty eradication amongst the most vulnerable groups; women in particular. The World Summit for Social Development held in Copenhagen in March 1995 underline the importance of improving access to credit schemes for people with low or no income with special consideration to the needs of women. Srinivas (2005) and Karlan (2005) agree that women approximately constitute 75 percent of all MCSs recipients worldwide. The United Nations (2012) re-affirms that Informal Women Traders (IWTs) engaged in MCSs could unleash the economic potential of hundreds of millions of the worlds' poorest which was not the case before. These international observations necessitate the quest to investigate poverty with regards to informal women traders and MCSs for poverty eradication involvement under economic and environmental hardships.

At regional level, in countries in the Sub-Saharan Africa, poverty eradication by women doing business at flea markets has become a common phenomenon that requires to be researched on. Mupambireyi (2014) confirms that developing countries have been plagued with a plethora of challenges which had scuttled economic growth. Richman (2009) added that regionally, MCSs by informal women traders at flea markets have also been done in countries like India, Ethiopia and Kenya. The Microfinance Bulletin (2006) substantiate that Asia comprises 70 percent of the world's microfinance account holders, Latin America made up another 20 percent, and the remaining 10 percent are scattered throughout the rest of the world. Earlier than now, the African continent comprised merely 4 percent of the overall population which had access to MCSs. The mainstreams of IWTs doing business at flea markets seem to prefer accumulating through MCSs for poverty eradication because of the growing realization of the need to improve standards of livelihoods of the poor. These and erstwhile studies authenticate that MCSs assist IWTs in making successful businesses by way of flea markets to unleash extreme poverty. Srinivas (2005) and the Grameen Bank (2012) corroborate by substantiating that attendance here is compulsory for the repayment of loan instalment and the collection of savings. IWTs meetings are likely to reinforce a culture of discipline, routine repayments and staff accountability. In India, a study on MCSs conducted in 2012 
revealed that 18 percent of the overall population especially women have some form of microfinance account which is bound to protect its members from whichever eventualities. Richman (2009) underline that poor women in Ethiopia, India, and Kenya have been excluded from government lending schemes or faced prejudice in banking systems other than benefiting from MCSs to form successful businesses to enhance their livelihoods.

Other MCSs success examples are documented in countries such as Latin America, Bangladesh, India, Thailand, Indonesia, West Africa, Southern Africa, Zimbabwe and Kenya amongst others. These practical experiences have shown that MCSs programmes extend small loans to very poor people for self employment projects that appear to generate income, allowing them to care for themselves and their families. The Grameen Bank in Bangladesh achievement has been considered the most prominent of the success stories reaching over 2 million people with cumulative lending of about USD2.1 billion. The Grameen Bank which is largely responsible for making available credit to women show that high payment rates is partly owing to the practice of weekly public meetings in the informal sector.

\section{Micro Credit Schemes And Flea Markets In Zimbabwe}

In Zimbabwe, many people, particularly informal women traders prefer to engage in various MSCs at flea markets for poverty eradication. Mupambireyi (2014) reveal that the phenomenal growth of informal trading is deeply rooted in the economic policies which government pursued especially after the first decade of political independence in 1980. The Zimbabwe World Report (2017) provides that Zimbabwean economy has been characterized by macroeconomic imbalances such as high budget deficits, balance of payment deficits, inflation and low economic growth. In Harare informal women traders endeavour to outsource sufficient livelihoods resources to address these imbalances. Zimstats (2013) and the Zimbabwe Poverty Report (2017) offer that Poverty and Poverty Datum Line Analysis (PDLA) in 2011/12 was pegged at 62.6 percent of households who are deemed poor whilst 16.2 percent are living in extreme poverty. The Poverty Datum Line (PDL) as defined by the Zimbabwe Poverty Report (2017) reflects the cost of a given level of living standard which must be attained if a person is deemed not to be poor. Zimstats (2019) figures show that poverty in Zimbabwe is very high (72.8 percent) among households without salaried workers as compared to those with a salaried worker (38.5 percent) living below the PDL. Figures substantiate that extreme individual poverty in Harare Province is (3.8 percent) (Zimstats, 2019).

Thus, informal Women Traders in urban centres are forced to employ a range of socio-economic activities for their livelihoods which amongst them include informal trading MCSs. Max (1995) recognizes MCSs as informal and semi-informal social security engagements provide livelihoods resources which are not only financial other than labour and moral support to the immediate social security needs of family members. Previous policies and legal frameworks have focused mainly on control and exclusion of IWTs who appear to be bypassed in opportunities to satisfy their quest for poverty eradication. The National Government over the years has been putting in place several poverty eradication strategies and interventions for its poor people living below the poverty datum line (PDL). The MCSs and flea markets have been gaining impetus nationwide because such schemes are likely to benefit those living below the 
PDL in the informal sector. However, many studies demonstrate that these are not governed by any legislation and have now become widespread throughout the metropolitan and provincial city centres to growth points nationally. Mupambireyi (2014) views flea markets as characterised by low barriers to entry, relatively low capital requirements and product homogeneity which in turn promote a high likelihood of new entrants in the market.

Nyakudya (2012) analysed the rise of flea markets and the findings revealed that flea markets and MCSs appear to be rising like phoenix from the ashes in all the ten provinces. Flea Markets and MCSs performances nowadays are anticipated to be the major sources of income for livelihoods as well as pathways towards poverty eradication. Such places nationwide have mushroomed, predominantly in the Central Business Districts. Flea markets and MCSs appear to sprout in all the provinces such that each district appears to becoming a centre of daily activities and these give the opportunity for IWTs to borrow money to enhance their businesses. The IWT individuals would then reimburse the loan later after a guaranteed period. MCSs for women doing business at flea markets in modern society is considered not only to support their entrepreneurship activities but instead have tended to empower those who have no family assets to serve as collateral security. The IWTs are required to have steady employment record that traditional lenders require most. Many IWTs appear illiterate or semi-illiterate and their efforts have tended to be hidden. Some IWTs are likely to be incapable to complete paperwork required to obtain conventional loans provided by some of the financial institutions. Those who borrow money are required to pay back the loan with interest whilst they use profits to support their families. In most cases, IWTs are bound to have expenses on items such as food, medical bills, school fees or any other uncertainties that may come about in the family. Mupambireyi (2014) confirm that "the grim picture in Zimbabwe demonstrates that the informal sector and flea markets are there to stay, until and unless a fundamental structural policy shift is adopted to stimulate investment and growth of the formal sector".

\section{Micro Credit Schemes And Flea Markets In Harare}

At a local level, informal women traders in the Harare have gained impetus as many MCSs have emerged like a phoenix from the ashes. More recently, there have been countless flea markets around the Harare Central Business District (HCBD). Even though there are countless flea markets around the metropolitan, this study focused specifically on a flea market located approximately in the Harare city centre. The flea market was chosen because of its proximity to the banks, big shops, and other enjoyable performances making it a leading flea market around Harare. Around this flea market, cinema is a remarkable lubricant for entertainment and it is forever full of life with different activities especially during weekends and school holidays. The flea market profits from a great experience of good transactions in addition to second class citizens who appear to wander around for entertainments and other intentions. Biriwasha (2011) corroborate stating that the flea market has its general stalls with people selling an assortment of goods from clothes, gadgets, children's toys, books and many more. As a result, numerous IWTs are doing business where they are always advertising second hand clothing, kitchen ware, imported new items as well as locally made products, traditional crafts whilst they engage in MCSs as individuals or groups. 
Eating and drinking here holds body and soul together for both consumers and flea market tycoons as no other flea market exists in the Harare metropolitan which made it feasible.

\section{Conceptual Overview}

The Sustainable Livelihood Approach (SLA) proffered by the Swedish International Development Cooperation Agency Division (SIDA, 2001) for Policy and Socio-Economic Analysis was adopted to guide this study. Krantz (2001) aver that the concept of Sustainable Livelihood (SL) is an attempt to go beyond the conventional definitions and approaches to poverty eradication. Several IWTs get involved in MCSs at flea markets for poverty eradication. Chambers and Conway (1992) describe Sustainable Livelihoods as the capabilities, assets together with both material and social resources and activities used by a household for means of living. A livelihood is sustainable only after which Chambers and Conway say people are bound to cope with and recover from stress and shocks, maintain or enhance its capabilities and assets, and provide sustainable livelihood opportunities for the next generation. Only this contributes to other livelihoods at the local and global levels and in the short and long term. The SLA approach captures diverse techniques that meet individual, household, and community essential requirements. Kantz (2001) discovered that the Institute for Development Studies (IDS) and the British Department for International Development (DFID) have been putting into operation the SL concept. Hence, this approach has been preferred for this particular study because it relies on various types of 'capital' and human, social, natural, physical, and financial, as well as socio-economic and political structures and processes at household level. At flea markets for example, IWTs plan MCSs to support their family units and thus reduce poverty. It facilitates access to capital, livelihood strategies and decision-making powers through processes, such as policies, legislation, institutions, culture, and power relations. The IWTs at flea markets take to the stage and chose to make a difference in poverty reduction as mostly are likely to be continually exposed to which ever form of challenges if there are no appropriate interventions by institutions. The most complex situation is the portfolio of assets out of which people construct their living, which includes both tangible assets and resources, and intangible assets such as claims and access (Krantz, 2001). Thus, pressure on livelihoods strategies of informal women traders at flea markets appear to increase and force them to live below the poverty datum line.

\section{Research Methodology}

A qualitative research design was adopted in this study. Units of study were selected using purposive sampling in which 20 informal women traders aged between 22 and 35 years were chosen. As well 6 key informants comprising of men undertaking business at the same flea market, who were knowledgeable on the nature of activities taking place were selected. Therefore the sample comprised 26 people in total. Data collection was guided by the Livelihoods Strategies developed by SIDA, (2001) and in-depth interviews, informal conversations, Focus Group Discussion (FGDs) and semi-participant observations were utilised to gather information on livelihoods strategies of informal women traders engaged in 
business at a flea market near the Harare Metropolitan Centre. Data were analysed thematically, with specific focus on themes and sub themes that constantly emerged through data collection.

\section{Ethics In Research}

Research ethics and privacy were observed with IWTs at the flea market. The researchers sought consent from the study participants themselves and made it clear that the collected information was going to be purely for academic purposes. The researchers were aware of the sensitive nature of the study and the implications of observing informed consent. Neuman (1997) cited in Chikoko, et al, (2019) define ethical considerations as what is or not legitimate to do or what is 'moral' when conducting a research. The names and places given in data presentation are not their real names and places. As such, pseudo-names were used throughout data presentation. All the study participants interviewed agreed to partake in the study and the collected information was kept in confidence to protect the study participants.

\section{Research Findings And Discussion}

The study investigated informal women traders involved in Micro Credit Schemes at the flea market for that particular period. The analysis of the qualitative data collected was based on the Sustainable Livelihood Approach by SIDA (2001) used to guide the study at the chosen flea market. The study discovered a variety of activities done by women at the flea market, explored the survival and coping challenges experienced by IWTs under economic and environmental hardships and finally, suggested comprehensive interventions and sustainable livelihoods strategies that could be used to out-scale and throw a lifeline to the informal women traders. There were many informal women traders involved in MCSs at the flea market that ranged from groups to individuals. The IWTs depended on MCSs as their source of livelihoods. Flea Markets have become attracting centres for women who want to do business and MCSs enhance the socio-economic development, setting standards for poverty eradication and improving the living standards of IWTs. The data were analysed with regard to the following sub themes; the nature of business, formation of MCSs, types of lending schemes, profit sharing and terms of payment, member's benefits of MCSs, challenges encountered, why women engage in micro credit schemes, the way forward and finally the conclusion.

\section{The Nature of Business}

The study established that generally, informal women traders have a long tradition of working together as groups based on social relationships which revolve around kinship ties, gender or village memberships. The nature of business was centred on MCSs as well as buying and selling assorted local and imported goods that ranged from traditional handicrafts, clothes, hand bags, blankets and kitchen wares to children's toys. Figure 1 shows the nature of businesses that IWTs were involved in at the time this study was conducted. 
The 20 informal women traders and 6 key informants interviewed were involved in MCSs at a particular flea market near the Harare Central Business District. In any case, 10 cited that they were selling mixed products which were handmade e.g. weaving, knitting, and crocheting whilst 5 were selling imported products from other countries. The other 5 reported that they were selling traditional products such as pottery, basketry, locally made weaved floor mats. The study established that for IWTs selling local products, their business was lower than those who were selling imported goods since they were cheaper than the local products. Due to economic choices and preferences, consumers preferred cheap materials regardless of quality. The researchers' observation was that the emergence of products from other countries had pushed aside the local products. This influenced the position of informal women traders in boosting income in a meaningful way in economic and environmental hardships.

\section{Nature of Micro Investment}

Many IWTs reported that they were involved in MCSs not governed by any legislation. Mupambireyi, (2014) confirm that "the informal sector operated outside the realm of official regulatory frameworks and workers are not registered, regulated or protected under the labour legislation and social protection". The IWTs decided to mobilize themselves and planned their MCSs of their level with affordable rules and regulations they could understand better. Through pooling the resources together based on the group or socio-economic ties to form MCSs (locally known as rounds or mukando) at the flea market, women grouped themselves in a participatory and comprehensive manner. That is; IWTs formed groups which could contribute a certain agreed amount of money per week or per month. Thus informal women traders decided amongst themselves on how they wanted to use the money though bound by a constitution which stipulated written down rules and regulations. The group rules guided the operations of their schemes on certain aspects for example registration, contributions, benefits and code of conduct. Zheke (2010)'s practical experiences of an international agency Catholic Relief Services (CRS) confirmed that when the group is too big, the group members can be sub divided into smaller units of (6 to 20) members to manage their schemes efficiently and effectively. The grouping process was reported to be very simple as it does not need any paper work. The groups were small and structured after preliminary meetings were held to decide how many should be in a group and how much each member was to contribute per day, per week, per month or per year. Zheke affirmed that normally interested groups are invited to join the rounds or mukando based neither on their educational background nor economic status but instead based on characteristics such as trust, honesty, reliability, and punctuality, savings potential and locality and many more. Erstwhile studies show that once the group is structured, members decide on when to meet and how they want to share the generated profits basing on the group constitution. By pooling financial resources together, women improved sources of livelihoods which ultimately increased resilience to shocks such as illness, death in the family and medical bills. In the event that a member changed a place of residence from the particular flea market to another, this disqualified one from being a member as it was assumed that departing member joined the group where she was going to operate from. One IWT did not join whichever group but rather decided to do a self motivated scheme for the reasons best known to her. The woman constructed a self contribution strategy and at the end used the 
money to purchase items from foreign countries which she sold at the flea market. The informal woman trader had this to say;

"I decided not to join the group but rather to do it alone and every day I put aside a certain amount. On the first day, I put aside one dollar, the second two dollars, the third three dollars and so forth until the end of the month in which I raised USD460 dollars for myself. I used the money to order new items or for any other contingencies and for me this works very well" (Interview with the informal woman trader 20 June 2018).

The MCSs arrangements fostered motivation amongst women who seized the stage and decided to make a distinction in their lives. Mugabu (2012) aver that the provision of MCSs in such a measure is to reduce the burden of poverty among households in which interveners can support such schemes such as loan procedures and paperwork, combined with accounting experiences especially access to formal sources of credit.

\section{Terms of Payment and Profit Sharing}

The IWTs provide financial support to their members by providing short term loans (merry go round) to their members and if an individual requires long term help, the members were likely to consider that under a special arrangement. The money contributed by members was not kept in whichever bank account other than alternatively circulating within group members where terms of payment were stipulated. Women doing business at the flea market shared profits after every six months and sometimes give each other groceries for example salt, sugar, salt, cooking oil and soap. Whilst some members unveiled that they received less than $\$ 200$ per term, the majority stated that they received above $\$ 500$ more than the others which showed variances in their administration. One more member expressed that she was raising money to pay a hospital bill in the amount of (USD1 800) for her uncle who was diagnosed cancer. MCSs at this particular flea market proved successful as these proved to enhance livelihoods as income generated was reasonable, improved the living standards, and set standards in poverty eradication. The MCSs had managed to send their children to school, access health care, improved their living standards, pay monthly rentals on time, buy new stands, and one member articulated that she was able to purchase a motor vehicle. Such an experience is similar the Grameen Bank, (2012) study which confirmed that MCSs allow women to care for themselves and their families. A few women reported that they still struggled to pay back the loan in different terms. Thus, informal women traders found themselves paying back the mortgage through other sources apart from the benefits through tokens or gifts from relatives which even made it difficult to translate into loan interest. Figure 2 shows terms of payment by numbers.

Despite the provided details that some study participants failed to pay back the loan completely, others expressed that they were capable to pay back the loan although somewhat had failed to pay back on time. Those who failed to pay back on time were fined an agreed amount. Whereas some women paid the agreed amount every week, others paid back on a monthly basis and had not been charged any interest whilst others were charged interest. Some members were comfortable with the terms of payment; others were not and uttered dissatisfaction with the terms of payment. Hence quite a few members complained 
with regards to the amount of payment, time of payment and the amount of interest payable to the lender. The women borrowed the agreed amount used to pay back the loan with or without interest charged on them.

\section{How Women used the Money Borrowed}

The amount agreed upon was usually very small and this indicated refunds were small which could possibly make it difficult for them to pay back the loan on time. Figure 3 shows how IWTs used the amount of money borrowed from other group members;

The ways the borrowed money was used ranged from; buying and selling was reported (4) food stuffs (5) and bus fare expenses (5), property investments (3), education (2) and health care (1). These findings show that the highest was food staffs whereas the lowest was medical bills. Berhane of Action Aid (2009) concur indicating that more resources in the hands of women mean better health and education for the whole family, as women are likely to spend the money on schools and medicines for their children.

\section{Reasons why Women Engaged in Micro Credit Schemes}

Zimbabwe Poverty Report (2017: 54) confirm that in urban areas, poverty was highest among households that depended mostly on own business. Thus, informal women traders decided to provide capital to the marginalized women who were unable to access loans. Such schemes facilitated the IWTs to gain access and control of livelihoods resources to eradicate poverty where their opportunities proved very limited otherwise. With the loans they receive from microfinance groups, beneficiaries reported that they were able to invest in such businesses and secure distribution channels and start making more money on a consistent basis for survival and copings. Purohit, (2012) corroborate stating that informal women traders engage in MCSs for empowerment and as resolute pathways to eradicate poverty. Figure 4 shows the selected reasons why informal women traders engaged in micro credit schemes of that nature.

This study revealed that IWTs engaged in MCSs for various. Amongst them sharing risks was reported (10), to plan for the future (2), economic reasons (3), pulling resources together (3) and for sharing experiences (2). The mainstream IWTs conveyed that the main reasons why vast majority joined MCSs was to provide them with a base from which they could protect themselves against variety of contingencies by sharing risks and pooling resources together for poverty eradication.

Since forever, informal women traders did not qualify for traditional loans provided by various Commercial Banks and that's why vast majority decided to join the MCSs as sources of livelihoods and for poverty eradication. Most of the time, poor women have no collateral security and funds to pay back the loans. Thus many of the microenterprise owners were capable to begin enduring the stretching and thickening Poverty Datum Line (PDL). As IWTs did not have a protected way to save the money, with the MCSs fortunately, IWTs proved capable to keep hard cash circulating around other members in order to purchase certain items and sell them later. 
Thus IWTs constantly showed interest in starting small scale businesses but indeed, this was difficult because of the country's current socio economic turn down with a geographical picture of poverty in Harare Province pegged at 31.1 percent (ZPR, 2017). Hurtley et al (1990) corroborated emphasizing that it is popular these days to promote MCSs or to give grants which are likely to be more sustainable in the long run. The circumstances now permit an informal women trader to do so using their own initiatives and this helps them not only to realize their potential but instead to gain access and control over scarce resources as a pathway towards poverty eradication. Numerous IWTs realize that it pays to do business at flea markets and venture in MCSs which can protect them from migrating to neighbouring countries to do business in dangerous zones. SIDA's Sustainable Livelihoods Approach advocates for policies, legislation whereas doing such business ventures in foreign countries where there is no framework in place to legally protect the IWTs would results in exposing them to social risky factors such as xenophobic attacks, HIV and AIDS, STIs among others. This is why SIDA (2001) indicates that there is need to access capital, livelihood strategies, and decision-making power through processes, such as policies, legislation. The involvement of women in MCSs leads to overall economic growth in drained countries as they acquire a steadier income which enables them to buy more products to sell and generate money for themselves for their livelihoods to eradicate poverty. Kofi Annan (2012) substantiate by contesting that MCSs is a wise investment in which women who are regarded as a minority group are able to venture into such initiatives even if they encounter social and economic challenges more than their female or male counterparts who are not part of the scheme.

\section{Challenges Faced by Women in Poverty Eradication}

The study found out that IWTs encountered numerous adversaries at the flea market. Mupambireyi's (2014) study reveals that those deposited involuntarily in the informal sector due to the Economic Structural Adjustment (ESAP) in the early 90 s are facing a raft of challenges among them, increased competition, depressed consumer demand and lack of proper working infrastructure Fig. 5 shows selected challenges experienced by IWTs for poverty eradication.

Women expressed that they faced challenges with regards to unpredictable weather patterns, harsh economic environment, lack of official legal binding scheme, lack of resources for them to enhance collaboration and networking with other women's groups. All conveyed that they encountered challenges in paying back the loan. Some women communicated that in the first place, when they borrowed money from the group, they did not fully understand the permissible terms associated with the loans. Women received loans with good terms but did not understand the requirements because vast majority had taken the loan without complete information on how they were to repay back the loan.

Environmental conditions were some of the challenges encountered by women doing business at flea market. For example, women communicated that some of the items they sold at the flea market were seasonal such that those selling winter and summer clothes faced challenges due to change of weather from winter to summer and vise vesa which left them with abundant stock after each season. This though affected their business and ability to pay back the loan. There were no proper structures to secure their items during rainy season. A few women stated they were sometimes forced to close their stalls as 
they certainly did not have proper roof or building structures over their heads during either hot or rainy season and for them their business was a loss.

The other challenge encountered by IWTs included personal problems such as paying school fees, hospital bills and rent which had been some of the good excuse for them not being able to pay back the loan within a stipulated period. Thus personal problems such as sickness and death in the family had been cited as the major cause for not opening the business for some time. A few members disclosed that they closed their businesses for days, weeks or even months to recover from grief and bereavement after losing their dear ones. In those days, they could not sell or even join the scheme to gain profit in a meaningful way.

The study revealed that being in deficient of proper management expertise and misuse of funds were some of the challenges experienced by a few members who expressed that this actually affected their business. Some women were said to misuse the money for luxury items instead of generating profits for the business as well as pay back the loan on time. One woman always mentioned "personal" items which some of the group members regarded as misuse of funds. When the researchers probed further for clarification on this response the study participant was undecided to clarify what she meant by the word "personal". There was lack of proper mechanisms to check-up on the proper use of funds amongst women micro-credit operators.

There was lack of subsidies, incentives and policy guidelines on MCSs for IWTs doing business at flea market towards poverty eradication which demonstrated that there were a few of the de-motivating factors. Several IWTs stated that when they tried to import goods for sale, occasionally these were confiscated at the border post or they faced hassles at the border post. Some IWTs additionally expressed that sometimes officials besieged a number of their goods demanding immigration declaration forms for some imported wares. IWTs uttered that in as much as they wanted to work according to the law and regulations but sometimes they were taken uninformed and as a result were forced to hide and not declare some of the goods. According to them, time and again, officials at border posts cashed on bribes from vendors who failed to prove that their wares had been officially declared at the country's designated entry points.

When IWTs declare goods at the border, time and again it was not written anywhere that one should have kept safe declaration forms for future reference. Murwira (2012) dispute that some vendors imported goods in bulk and sold them at different flea markets across the country which made it difficult to keep the required declaration forms at all venues. Thus border post officials tend to note that deceptive vendors miss out declaration processes at each country's entry points moreover depriving the state millions of dollars in revenue. Murwira (2012) points out that those officials would track them down and collect what is due to the state.

\section{The Way Forward}


Comprehensive policies and programmes targeting IWTs are the most appropriate strategies for poverty eradication in Zimbabwe, predominantly in the inner cycles of major cities like the Harare. The Zimbabwe Poverty Report (2017) acknowledges that eradicating poverty is a top priority of the Government's overall policy objective, which stems from the country's development blue print, the 'Zimbabwe Agenda for Sustainable Socio-Economic Transformation (Zim Asset). The Sustainable Livelihoods Strategy propounded by SIDA, (2001) put emphasis on the realization that poverty - as conceived by the poor themselves; is not just a question of low income, but also includes other dimensions such as bad health, illiteracy, lack of social services, etc., as well as a state of vulnerability and feelings of powerlessness in general. These require immediate intervention strategies through re-enforcing policies and programme that target IWTs involved in MCSs at flea markets. The Zimbabwe Poverty Report (2017) for example provides that; "eradicating poverty is a top priority of the Government's overall policy objective, which stems from the country's development blue print, the 'Zimbabwe Agenda for Sustainable Socio-Economic Transformation" (Zim Asset), October 2013-December 2018. The Sustainable Livelihoods approach propounded by SIDA suggests that there is need to access capital, livelihood strategies, and decisionmaking powers through processes, such as policies, legislation, institutions, culture, and power relations. The IWTs were found involved in MCSs at flea markets for livelihoods as pathways towards poverty eradication. As expressed by IWTs there are many challenges in their endeavours. The study established that IWTs doing business at flea markets could do well with adequate support from central Government and local institutions without charging exorbitant prices at their place of work. The study discovered that there is need for local authorities to advertise the business on their behalf and this could possibly be done by creating external links or external markets worldwide as much as possible.

Several MCSs were initiated by IWTs themselves without government or NGO support motivating them. However, examples could be drawn from other countries where these schemes are found to be successful. The Government and Financial Institutions could possibly have a role to play in assisting IWTs doing business at flea markets by giving those incentives for them to gain access and control over a number of available resources. In interview, IWTs expressed that they needed support (not remote control) in their initiatives from proficient agencies with expertise through effective monitoring and evaluation in order for them to address the problem of maladministration amongst themselves. This is proffered by the Sustainable Livelihoods Strategy which support that IWTs need polices and legal frameworks as a form of control. The United Nations Development Fund for Women (UNIFEM) suggested that MCSs were one of the key strategies to facilitate IWTs end their own poverty. This study therefore recommends the involvement of some financial institutions such as the World Bank, Global Fund for Women, Agri-Bank, Small and Medium Enterprises (SMEs), NGOs and many other financial institutions and a few small businesses. These may possibly need to provide soft loans to IWTs doing business at flea markets so as to enhance their businesses and gain access and control of the resources for their livelihoods. Nyakudya (2012) evaluated the growing panacea in which he argues that businesses of flea markets are now overcrowded but overlooks the aspect of the potential of MCSs engaged by IWTs whilst they are doing business at the flea market. There is great need for the Government to instate laws and regulations that will see every flea market and MCSs fitting in with the Zimbabwe Constitution of 2013 and the 
Government ZIMASSET Document. The Government policy documents already launched could possibly establish opportunities through Commercial Banks for IWTs doing business at flea markets to benefit towards poverty eradication.

The study established that women involved in MCSs at flea markets encounter challenges in administering funds as well as paying back loans. The World Summit for Social Development held in Copenhagen in March 1995 called on Governments to review national, legal regulatory and institutional frameworks that restrict the access of poor women, especially. Kantz (2001) argues that depending on the agency, the approach could be used largely as an analytical framework (or tool) for programme planning and assessment or as a programme in itself. There is need to craft and implement policies and legal frameworks that introduce the provision of incentives to informal women traders at flea markets for them to enhance their capacities to do business as well as protect the interests of women doing business at flea markets for poverty eradication.

International Non Governmental Organizations like CARE as well as UNDP and DFID support household livelihood security mainly at community level. All these agencies emphasize the same sustainable livelihoods approach in enabling policy environments, macro-economic reforms, and legislation which are all equally important for effective poverty reduction. In that regard, there is great need for a multistakeholder approach through these various agencies as some of the agencies embrace regional financial institutions and other donor agencies involved in the eradication of poverty, such as IFAD, ILO, World Bank, UNDP and UNICEF. The SLA has to be done together with IWTs doing business at flea markets to promote vibrant micro credit schemes that help in the process to eradicate poverty. The thrust of a multi-stakeholder approach in the same way initiate comprehensive micro-credit management training programmes that are in line with the aspirations of the World Summit for Social Development of March 1995. The SL Approach could produce a more holistic view on what resources, or combination of resources, are important to the poor, including not only physical and natural resources, but also their social and human capital (Kantz 2001). This could perhaps embrace massive trainings of IWTs in business management; capacity building workshops, education on HIV and AIDS, gender issues and leadership workshops all required to enhancing the livelihoods of women involved in MCSs at flea markets as pathways towards poverty eradication. Hence, if these interventions and sustainable strategies for this meticulous group are made in line with the SIDA SLA, this could effectively empower IWTs for poverty eradication. Kantz (2001) corroborates that the SLA has its strength in that "it facilitates an understanding of the underlying causes of poverty by focusing on the variety of factors, at different levels, that directly or indirectly determine or constrain poor people's access to resources/assets of different kinds, and thus their livelihoods". Kantz (2001) reminds that the SLA has its weaknesses in that the way resources and other livelihood opportunities are distributed locally is often influenced by informal structures of social dominance and power within the communities themselves; the issues which the UNDP and CARE seem not to address. These issues affect the livelihoods of informal women traders doing business at flea markets in the inner cycles of the HCBD in Zimbabwe. 


\section{Conclusion}

This study investigated the livelihoods strategies of the informal women traders doing business as a strategy to eradicate poverty in Zimbabwe. The study was carried out at one of the flea markets in the Harare Province. The study was informed by the Livelihood Framework proffered by SIDA, (2001) specifically for poverty eradication. The specific objectives of the study were designed; to discover micro credit schemes by IWTs doing business at flea markets, to explore the impact of MCSs as pathways towards poverty eradication and the challenges experienced by women doing business at flea markets; to determine various survivals and sustainable coping strategies that could be used by informal women traders under harsh socio-economic environment and finally, to determine possible interventions and sustainable strategies that could be used to out-scale and throw a lifeline to the IWTs. Data was gathered through interviews, focus group discussions and observations. The study revealed that IWTs specialise in MCSs as their sources of livelihoods, flea markets have become attracting center for women who want to do business in the HCBD. The MCSs enhance socio-economic development, set standards in poverty eradication and improves the standards of IWTs. Many encountered numerous challenges resulting in finding it difficult to repay back the loans. The study concluded that if financing institutions and Non Governmental Organizations could give them assistance through small bank loans; this would help them to gain access and control of their livelihoods resources in a meaningful manner. The study proposed a few livelihoods strategies that could be in the form of Macro Micro Credit Schemes (MCSs) financed by big institutions such as Global Fund for Women and International Monitory Fund. The instruments free IWTs from poverty as well as increasing their participation in the economic and political processes of society in Zimbabwe.

\section{Declarations}

The work was conducted under the Department of Social Work of the University of Zimbabwe by Stella Chipo Takaza and Chipo Chitereka. We understand the methods used in this article and we declare that the principal work contained in this article is original work and we are the responsible persons. This Journal gets the sole and exclusive right to publish the work for the full length of the copyright period and permissions for reproduced work. The article has not been previously published and is not under consideration elsewhere.

\section{COMPETING OF INTERESTS IN THE FIELD}

The research was conducted with the support some well respected stakeholders as part of an academic exercise. The collaborative efforts enabled the researchers to gain access to the informal women traders at the site.

\section{AVAILABILITY OF DATA AND MATERIAL}

Permission to collect data was sought from the local authorities who granted approval to access the study participants within their business premises. The informal women traders made decisions to 
participate in the study after adequate information was given that data after collection was for academic purposes. There was no coercion or any undue influence. The researchers assured the participants maximum confidentiality and anonymity through using numbers instead of names on the questionnaire tool guides.

\section{AUTHORS' CONTRIBUTIONS}

The authors took part and guided the study and their inclusion to the publication has been gained and no one is 'ghost' writer.

\section{FUNDING}

The research project was self funded and no funding was received from anywhere else except from the initiatives of the researchers.

\section{ACKNOWLEDGEMENTS}

We would like to thank all the women informal traders who volunteered to participate in this study and shared their thoughts and feelings on the topic under investigation. We would like to thank all the informal women traders who freely shared their experiences in their businesses to fight poverty. Without all your generous support, this survey would not have been successful. We thank you all.

\section{References}

Richman. D. (2009). Microcredit Schemes creates strong independent businesswomen: Independent Ethiopia. www.independent.co.uk-News-World-Africa Accessed 5/05/ 2018

Donnacadh, H., Duke, S., Francis, R. and Pratt, B. (1990). Income Generation Schemes for the urban poor; Development Guidelines No.4, Series Editor: Brian Pratt.

Krantz, L. (2001). The Sustainable Livelihood Approach to Poverty Reduction: An Introduction thesustainable-livelihood-approach-to-poverty-reduction_2656(3).pdf

Kaseke E. (1995). Social Security and Redistribution: The Case of Zimbabwe's Social Security programmes. Westport, Green word Press.

Kasende, D., Asingwuire, N., Kyomundo, S. and Banungire, F. (2001). A Regional research project-Final Report for Uganda Country Studies Phase 11.Uganda

Mugabi N. (2010). A dissertation submitted to the Department of Sociology, Faculty of Social Sciences in partial fulfilment for the award of the Degree Master of Arts in Sociology of Makerere University.

Mupambireyi, P. F., Chaneta, I. \& Maravanyika, D. (2014). Operational challenges of informal trading: A case of Mbare Mupedzanhamo Flea Market in Harare, Zimbabwe. University of Zimbabwe Business 
Review, 2 (2), 77-87.

The World Bank, (1990). The Informal Sector In Zimbabwe: The Role of Women. The World Bank PHRWD Washington

Zheke, H. (2010). Savings and Internal Lending Communities (SILC): The key to helping Zimbabwean Youth overcome Poverty-Harare.

Zimstat. (2017). Zimbabwe Poverty Report 2017. Harare: Zimbabwe National Statistics Agency.

Mupambireyi, P. F.; Chaneta, I; Maravanyika, D., (2014) Characterisation Of Traders In The Clothing Flea Market Business: A Case Of MbareMupedzanhamo And Avondale Flea Markets In Harare, Zimbabwe Researchjournali's Journal of Entrepreneurship Vol. 2 | No. 10 December | 2014

www.grameen-info.org/what is micro-credit Accessed 16/ 01/2019

www.ziviso.wordpress.com/2011/07/30/Avondale-flea-market, Avondale's Flea Market: Harare's Bargain Bonanza, Chief K. Marimba Biriwasha- Accessed 25/01/2019

\section{Figures}

\section{Nature of Business by Percentage}

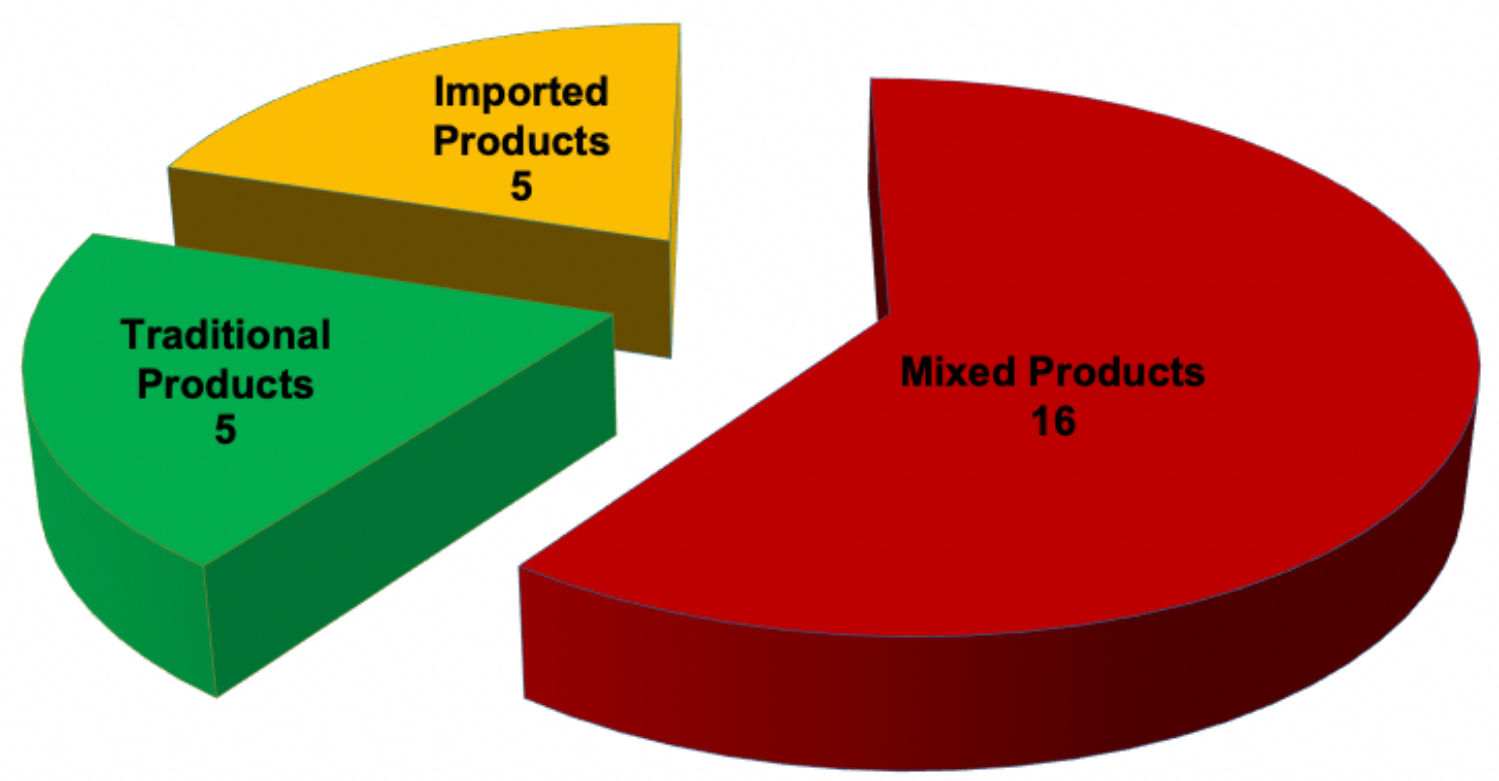

Figure 1

The Nature of Business 


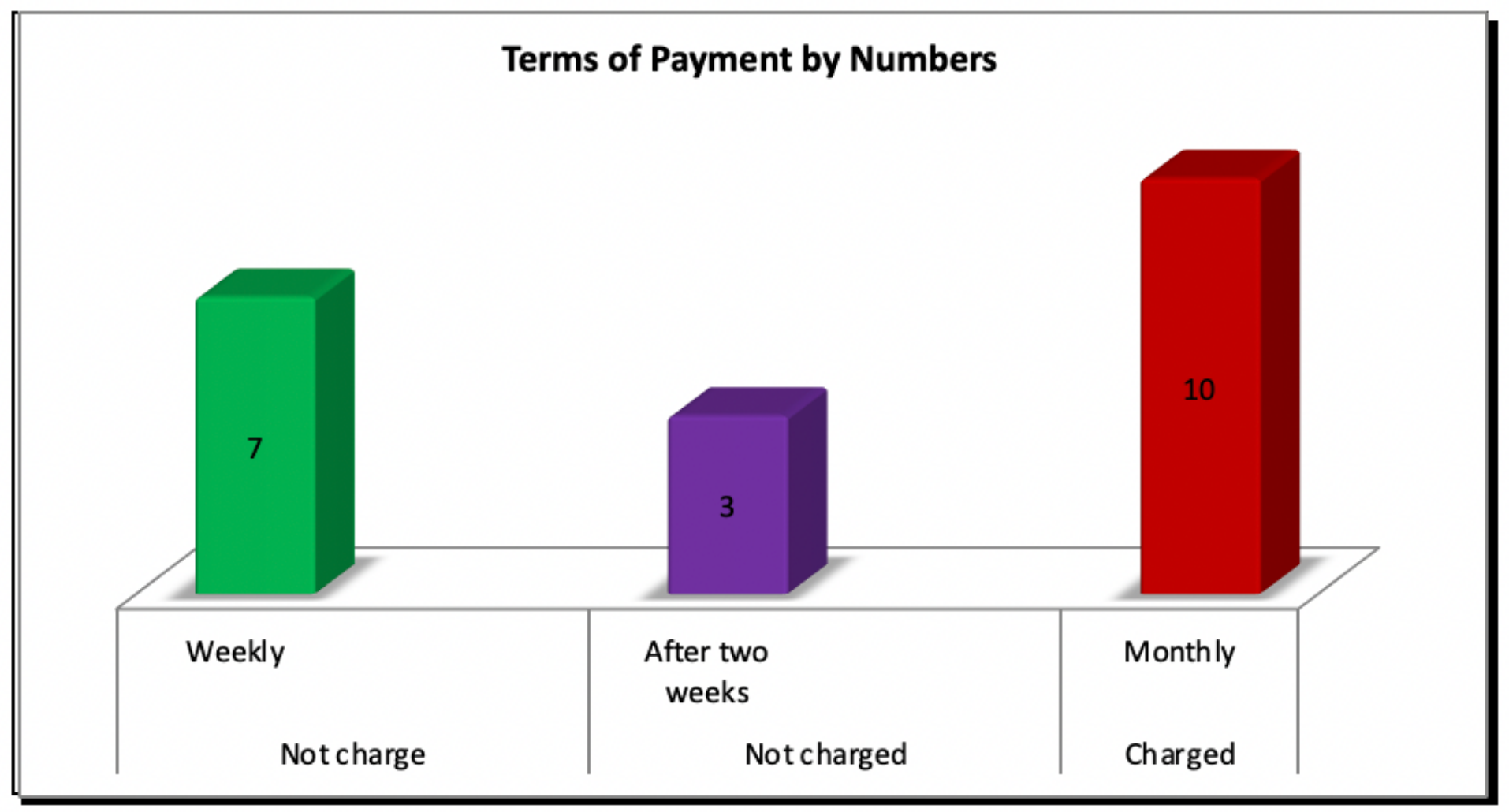

Figure 2

Terms of Payment by Numbers

\section{How Women used the Money Borrowed}

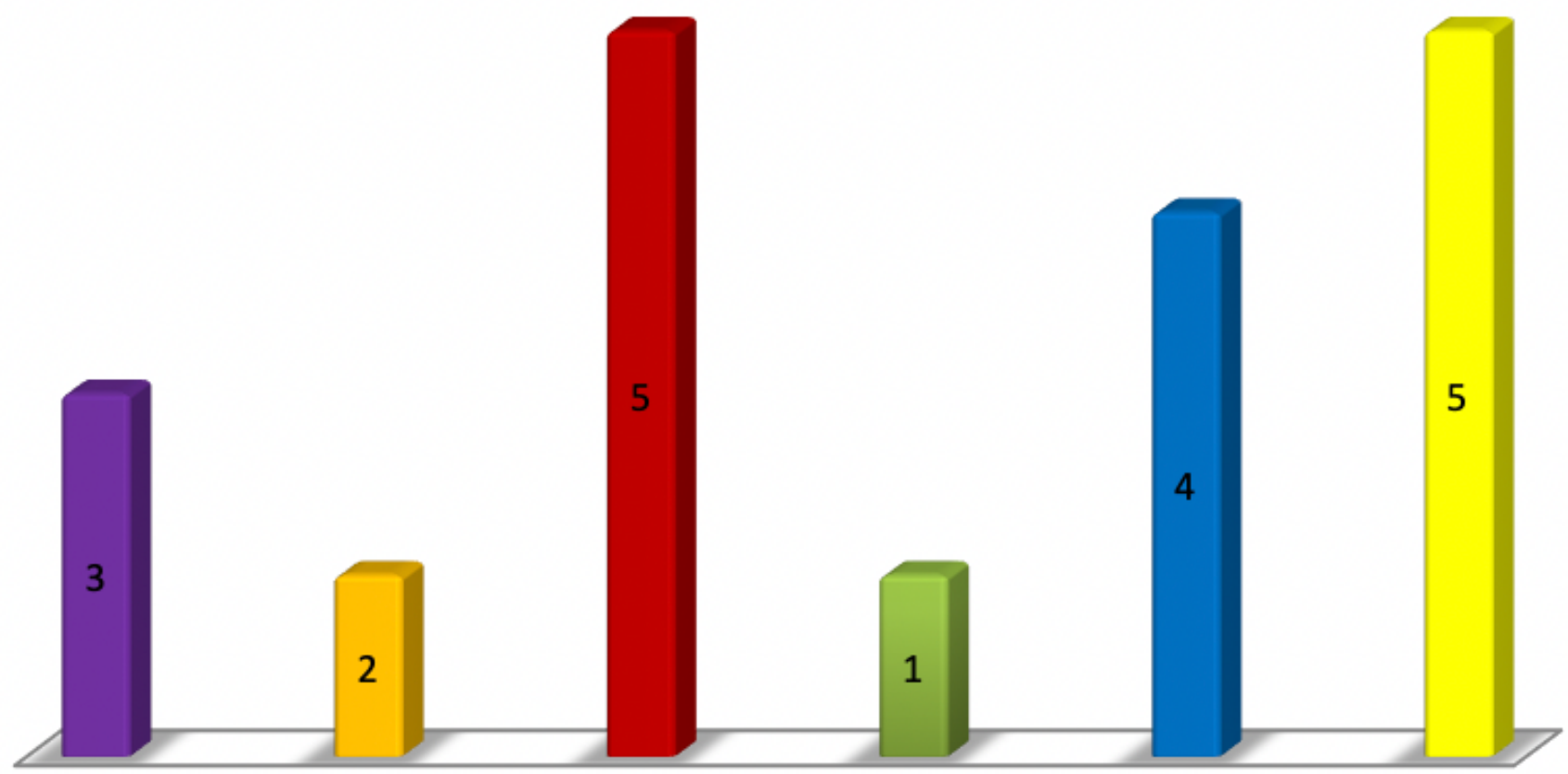

Health care Food stuffs Education Buying and selliing Bus fare 
Figure 3

How Women used the Money Borrowed by Numbers

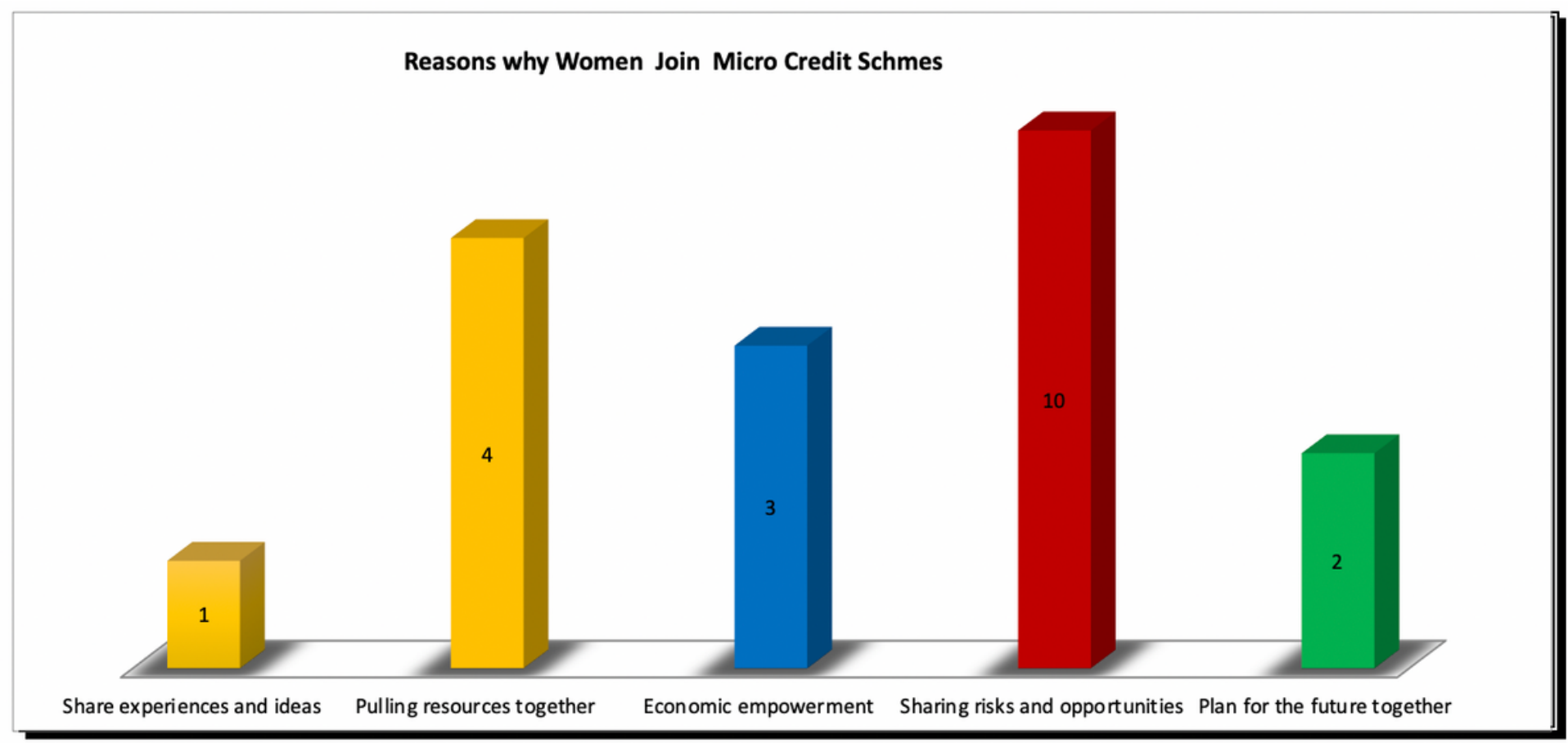

\section{Figure 4}

Reasons why Women Join Micro Credit Schemes

\section{Challenges Encountered by Informal Women Traders by NUmbers}

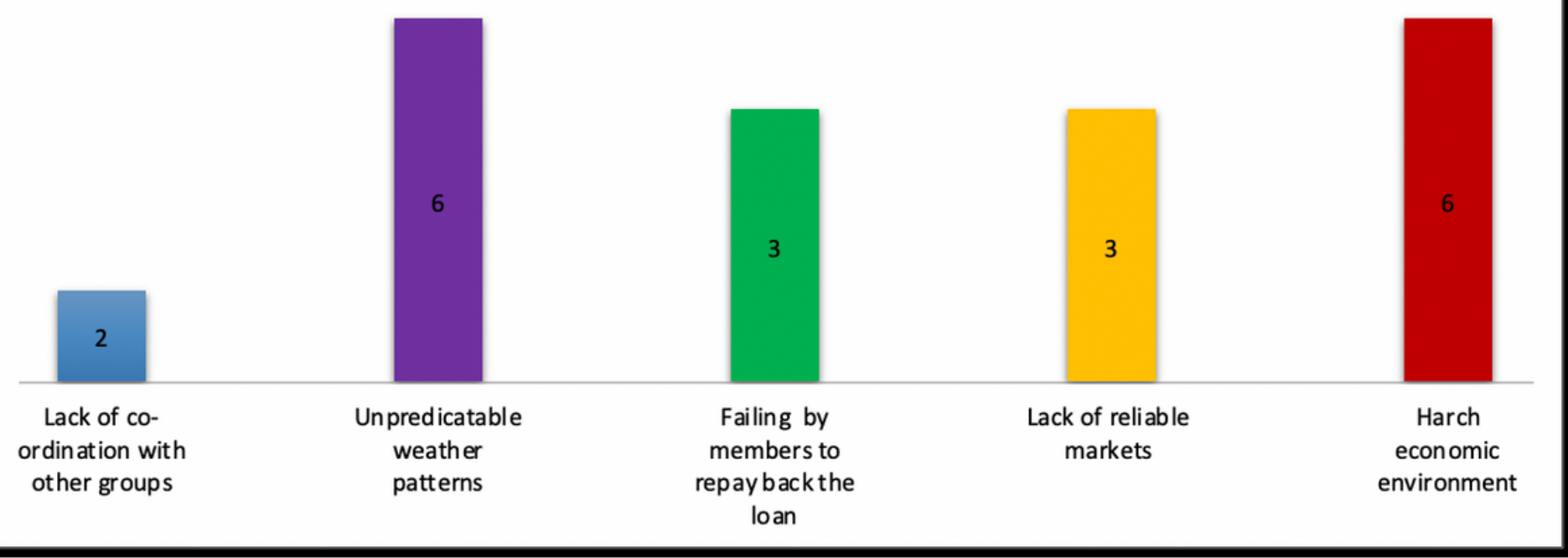

\section{Figure 5}

